
May 2002
-
NREL/CP-520-31399

\title{
Spectral Corrections Based on Optical Air Mass
}

\section{Preprint}

K. Emery and J. DelCueto

National Renewable Energy Laboratory

W. Zaaiman

European Commission Joint Research Centre Institute for Environment and Sustainability

To be presented at the $29^{\text {th }}$ IEEE PV Specialists Conference New Orleans, Louisiana May 20-24, 2002

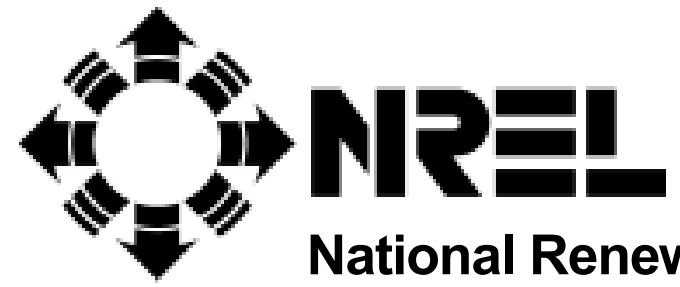

1617 Cole Boulevard Golden, Colorado 80401-3393

NREL is a U.S. Department of Energy Laboratory Operated by Midwest Research Institute $\bullet$ Battelle $\bullet$ Bechtel Contract No. DE-AC36-99-G010337 


\section{NOTICE}

The submitted manuscript has been offered by an employee of the Midwest Research Institute (MRI), a contractor of the US Government under Contract No. DE-AC36-99G010337. Accordingly, the US Government and MRI retain a nonexclusive royalty-free license to publish or reproduce the published form of this contribution, or allow others to do so, for US Government purposes.

This report was prepared as an account of work sponsored by an agency of the United States government. Neither the United States government nor any agency thereof, nor any of their employees, makes any warranty, express or implied, or assumes any legal liability or responsibility for the accuracy, completeness, or usefulness of any information, apparatus, product, or process disclosed, or represents that its use would not infringe privately owned rights. Reference herein to any specific commercial product, process, or service by trade name, trademark, manufacturer, or otherwise does not necessarily constitute or imply its endorsement, recommendation, or favoring by the United States government or any agency thereof. The views and opinions of authors expressed herein do not necessarily state or reflect those of the United States government or any agency thereof.

Available electronically at http://www.osti.gov/bridge

Available for a processing fee to U.S. Department of Energy and its contractors, in paper, from:

U.S. Department of Energy

Office of Scientific and Technical Information

P.O. Box 62

Oak Ridge, TN 37831-0062

phone: 865.576 .8401

fax: 865.576.5728

email: reports@adonis.osti.gov

Available for sale to the public, in paper, from:

U.S. Department of Commerce

National Technical Information Service

5285 Port Royal Road

Springfield, VA 22161

phone: 800.553 .6847

fax: 703.605.6900

email: orders@ntis.fedworld.gov

online ordering: http://www.ntis.gov/ordering.htm

Printed on paper containing at least $50 \%$ wastepaper, including $20 \%$ postconsumer waste 


\title{
SPECTRAL CORRECTIONS BASED ON OPTICAL AIR MASS
}

\author{
Keith Emery ${ }^{1}$, Joseph DelCueto ${ }^{1}$, and Willem Zaaiman ${ }^{2}$ \\ ${ }^{1}$ National Renewable Energy Laboratory, USA \\ ${ }^{2}$ European Commission Joint Research Centre, Institute for Environment and Sustainability, Renewable Energies, Italy
}

\begin{abstract}
The measurement of the photovoltaic (PV) performance with respect to reference conditions requires measuring the performance with respect to a reference spectrum. Procedures were developed in the mid 1980s to correct measurements for errors relating to the spectral irradiance of the light source being different from the standard and the responsivity of the irradiance detector being different from the device under test. In principle, these procedures are exact, but require the measurement of the spectral irradiance of the light source and responsivity of the test device. This is problematic for most facilities that measure module performance. It has been suggested that a polynomial fit of the short-circuit current $\left(I_{\mathrm{sc}}\right)$ measured under natural sunlight divided by the total broadband irradiance as a function of air mass provides an accurate spectral correction factor. The polynomial correction factor is normalized to unity at an absolute air mass of 1.5. The polynomial correction factor is compared with the spectral correction factor for a variety of devices at two locations.
\end{abstract}

\section{INTRODUCTION}

Measurements of PV performance under natural sunlight with respect to standard reference conditions require translating the data to the reference irradiance, spectrum, and temperature. This paper compares two methods for correcting the data to the reference spectral irradiance. The spectral correction factor provides a means to exactly correct the measured current to an arbitrary tabular reference spectral irradiance distribution. Because all reference spectral irradiance distributions are only a function of wavelength, with angular information not included, the spectral correction factor can be written as [1]

$$
C V=\frac{\mathrm{I}_{\mathrm{Sc}}}{\mathrm{E}_{\text {tot }}} \frac{\int_{0.3 \mu \mathrm{m}}^{4.0 \mu \mathrm{m}} \mathrm{E}_{\mathrm{R}}(\lambda) \mathrm{S}_{\mathrm{T}}(\lambda) \mathrm{d} \lambda}{\int_{0.3}^{4.0} \mathrm{E}_{\mathrm{R}}(\lambda) \mathrm{S}_{\mathrm{R}}(\lambda) \mathrm{d} \lambda} \frac{\int_{0.3}^{4.0} \mathrm{E}_{\mathrm{S}}(\lambda) \mathrm{S}_{\mathrm{R}}(\lambda) \mathrm{d} \lambda}{\int_{0.3}^{4.0} \mathrm{E}_{\mathrm{S}}(\lambda) \mathrm{S}_{\mathrm{T}}(\lambda) \mathrm{d} \lambda}
$$

where $E_{\text {tot }}$, is the total irradiance, $E_{R}(\lambda)$ is the spectral irradiance of the reference spectrum, $E_{S}(\lambda)$ is the spectral irradiance of the solar spectrum, $S_{R}(\lambda)$ is the spectral responsivity of the reference detector, and $S_{T}(\lambda)$ is the spectral responsivity of the test device whose measured short-circuit current is $\mathrm{I}_{\mathrm{sc}}$. If the reference detector is a thermal detector then $S_{R}(\lambda)$ is constant and drops out. The units of spectral irradiance are $\mathrm{Wm}^{-2} \mu \mathrm{m}^{-1}$. The units of spectral responsivity are $\mathrm{AW}^{-1}$ for a semiconductor-based reference detector and $\mathrm{VW}^{-1}$ for a thermal detector such as a pyranometer. If a pyranometer is used as the reference detector to measure the total irradiance, then $S_{R}(\lambda)$ is constant and drops out. Commercial spectroradiometers cannot measure the spectral irradiance from $300 \mathrm{~nm}$ to 4000 $\mathrm{nm}$, so an additional uncertainty in the spectral correction factor is introduced by limiting the range of spectral correction to a Si-based detector of $300 \mathrm{~nm}$ to $1100 \mathrm{~nm}$ [2].

It has been suggested that a fourth-order polynomial fit of $\mathrm{I}_{\mathrm{sc}}$ divided by the total broadband irradiance as a function of air mass provides an accurate spectral correction factor [3]. The polynomial correction factor is normalized to unity at an absolute air mass of 1.5. Corrections based on the absolute air mass are most accurate when the reference spectrum is close to the "AM1.5" spectrum at the test site. The uncertainty in air-mass correction factor can be reduced to zero if a matched reference cell is used instead of the traditional broad-band pyranometer. In principle, if a detector calibrated for the reference spectrum has an identical relative spectral responsivity, then the spectral correction factor is unity and the air-mass correction factor is unity. If an airmass correction factor used by one group is also used by another group, then the same reference detector should be used. This is especially true for amorphous silicon or other technologies whose spectral responsivity is over a narrow range. Spectral modeling allows an estimate of the sensitivity of the spectrum at AM1.5 to water vapor and turbidity. The error in the air-mass correction procedure is less than $\pm 2 \%$ for Si when using a spectrally flat detector over a broad range of turbidity and precipitable water vapor [4]. However, amorphous silicon has a much higher sensitivity to water vapor and turbidity than crystalline $\mathrm{Si}, \mathrm{CdTe}$, or CulnSe ${ }_{2}$ [4].

Figure 1 compares the calibration value for a monocrystalline-Si module with and without spectral corrections. The air-mass-corrected value was $1.3 \%$ lower than the spectrally corrected value using a linear fit and $3.8 \%$ lower using a polynomial fit as suggested by King et al. [3]. The data were collected at zero incidence angle. For the curve fit to be most accurate, the data should all be collected on the same day and the calibration value over a wide range of air masses must include data above and below air mass 1.5. Figure 2 shows direct-normal data collected all day on an encapsulated $\mathrm{Si}$ cell on four clear days at NREL. The Aspire reference cell is used as an irradiance detector for measurements under natural and simulated sunlight [7]. The air-mass correction factor varied by less than $0.4 \%$ for the 4 days, but predicted a calibration value that was almost $2 \%$ 
greater than the value predicted by rigorous spectral corrections using Eq. 1. These values are within expectations for the sensitivity to the calibration value at air mass 1.5 as a function of turbidity $(0.02-0.42)$ and water vapor $(1-2.5 \mathrm{~cm})$ based on spectral modeling [4].

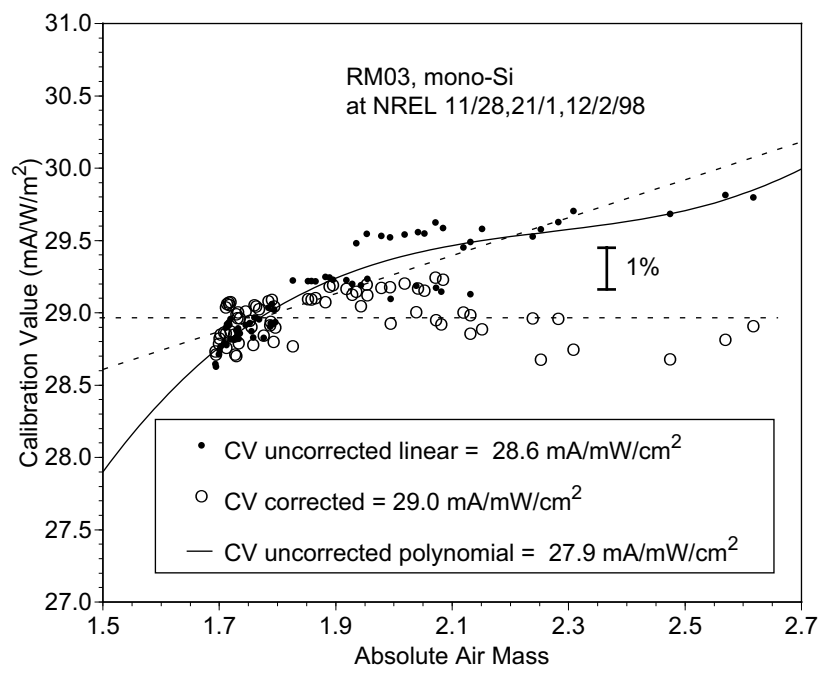

Fig. 1. Calibration value of a module under global sunlight compared with spectral correction for the global reference spectrum [5].

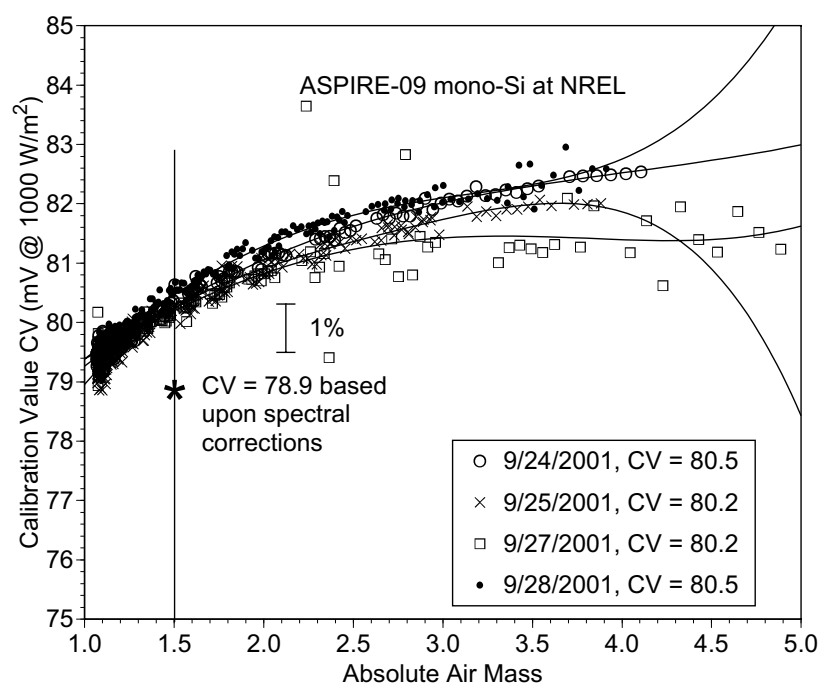

Fig. 2. Calibration value of a cell under direct-normal light with air-mass correction compared with spectral correction to the ASTM E891 direct reference spectrum [6] for 4 days.

For many applications, this difference is insignificant, and the cost and convenience of not calculating the spectral correction factor is important. The differences can be unacceptably large for narrow-response-range devices such as the filtered Si cell simulating the spectral responsivity of amorphous silicon shown in Figure 3 or the GaAs filtered GalnAsN cell with a 900-1200 $\mathrm{nm}$ response range shown in
Figure 4. Figure 5 shows the sensitivity of the air-mass spectral correction factor to operator judgment and day showing over a $1 \%$ spread in the AM1.5 calibration value. The linear fit is quite different depending on whether all points are included or points with an air-mass less than 5. Applying a fourth-order polynomial fit to the entire November 23 data set in Figure 5, as suggested in reference 1, gives a calibration value of 78.6 , or $3 \%$ lower. This is partly because the data are being extrapolated to a pressure-corrected value of AM1. 5 because it could not be reached at this site elevation at this time of year.

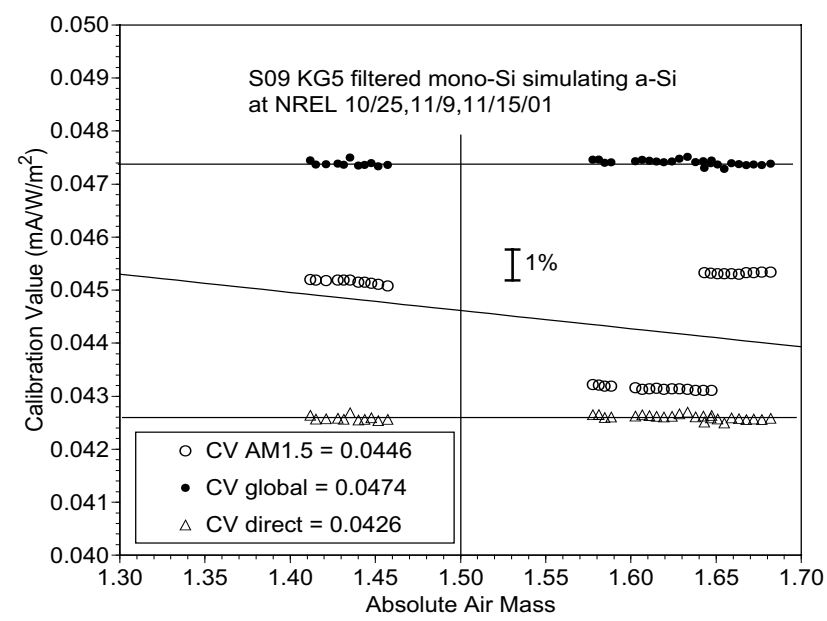

Fig. 3. Calibration value of a Schott KG5 filtered Si reference cell under direct sunlight $\left(5^{\circ}\right.$ field of view) with airmass correction compared with spectral correction. The AM1.5 corrected value is $5.9 \%$ lower than the spectrally corrected global value and $4.7 \%$ greater than the spectrally corrected direct-normal value.

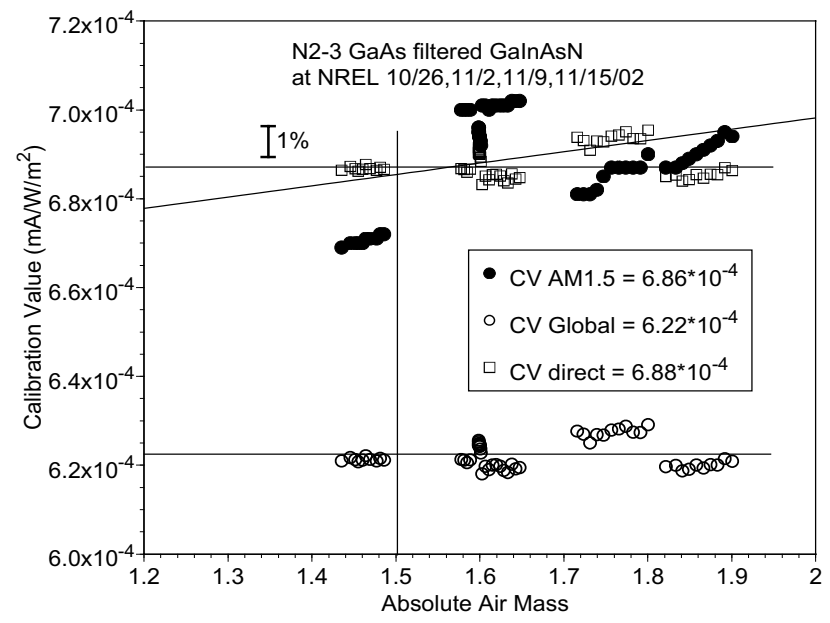

Fig. 4. Calibration value of a narrow response range GaAs filtered GalnAsN reference cell under direct-normal with airmass correction compared with spectral correction. The AM1.5 corrected value is $8.9 \%$ lower than the spectrally corrected global value and $1.5 \%$ greater than the spectrally corrected direct-normal value. 


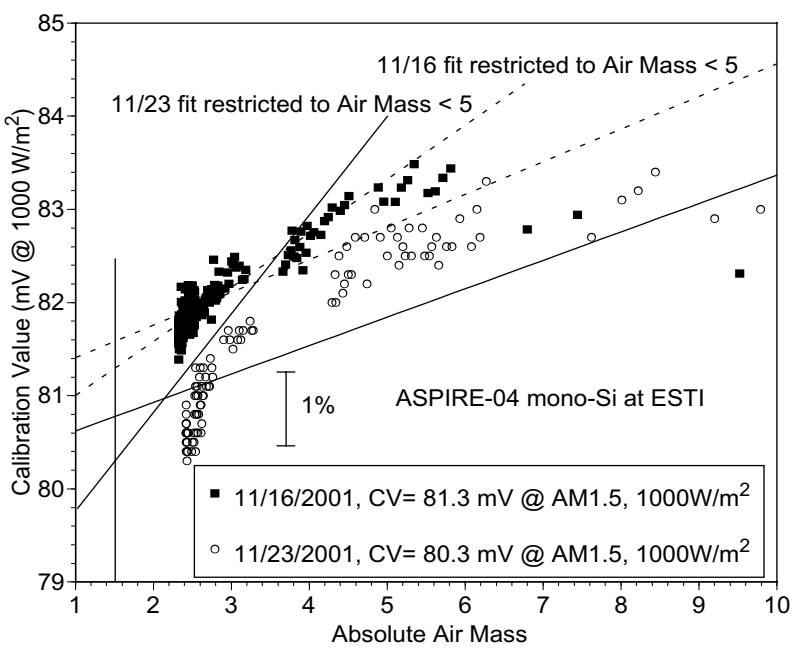

Fig. 5. Calibration value at AM1.5 is a function of the day the data are taken, the range of air masses that the data are collected over, and type of curve fit used.

Figures 6 and 7 show the seasonal and daily variation in the temperature corrected calibration value for CIS and CdTe modules respectively for several days near the solstices and equinox's. The data was filtered for clear sky conditions and incidence angles less than $50^{\circ}$. The latitude tilt data was collected at NREL over several years. The symbols for the data near the solstices are solid, while the symbols near the equinox's are open.

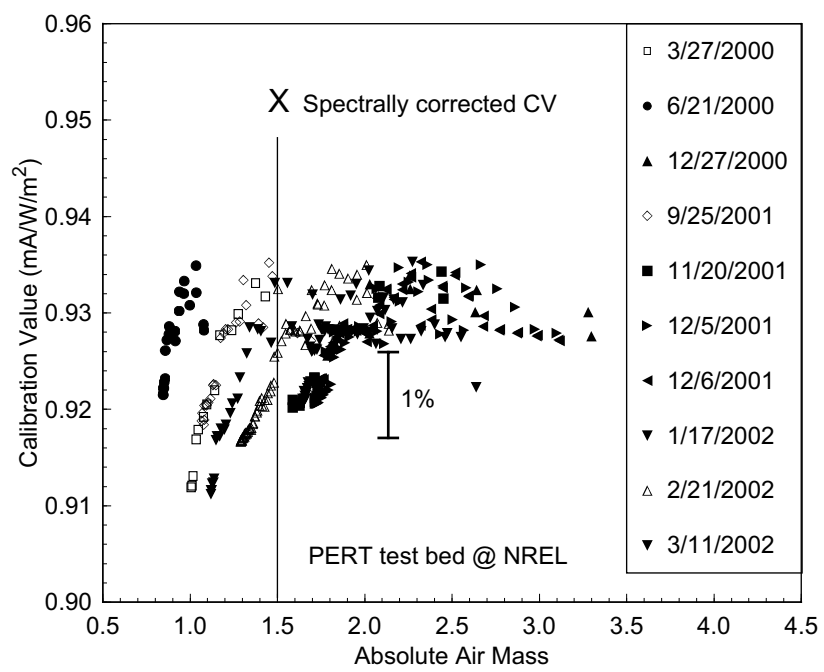

Fig. 6. Calibration value as a function of air mass for a CdTe module mounted at a fixed tilt.

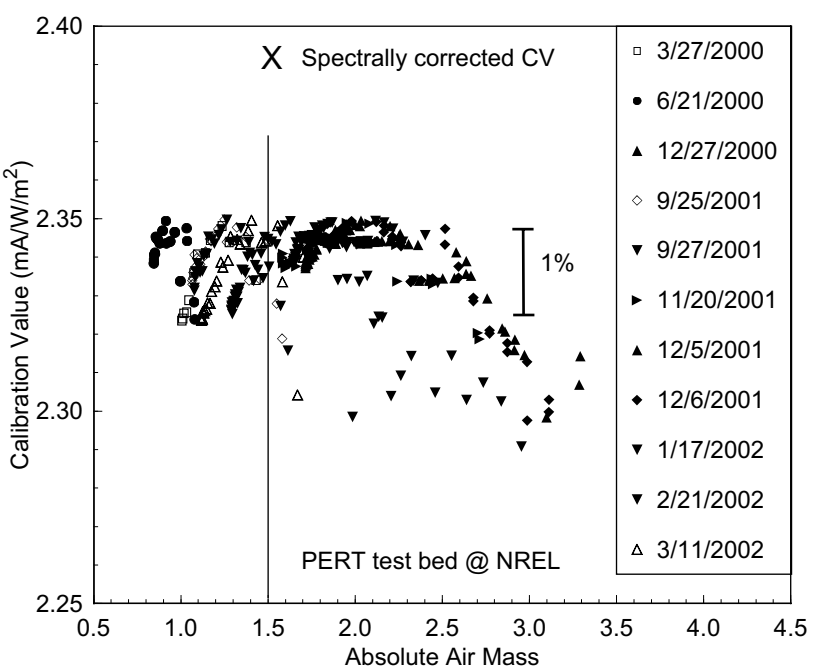

Fig. 7. Calibration value as a function of air mass for a CIS module mounted at a fixed tilt.

From a standards perspective, it is difficult to estimate the uncertainty in the air-mass spectral correction procedure because it does not correct the data to a tabular reference spectrum. Modeling the spectral sensitivity allows the estimation of the uncertainty over a range of turbidities and precipitable water vapor encountered [4]. Following the modeling algorithms in reference 4, Figures 8 and 9 show the percent deviation from the reference spectrum over a range of precipitable water vapor and turbidity at air mass 1.5 that may be encountered in the field.

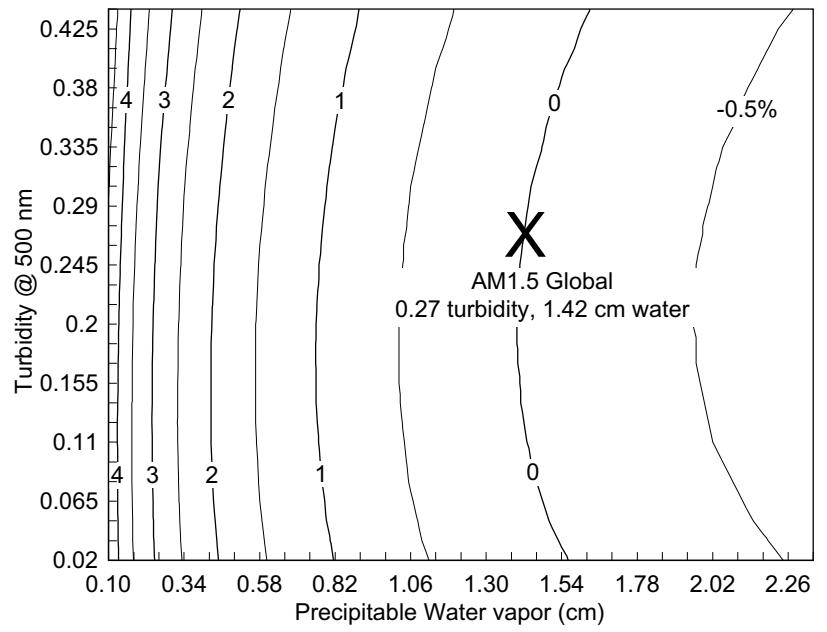

Fig. 8. Percentage deviation from the global reference spectrum at AM 1.5 for a mono-Si module. 


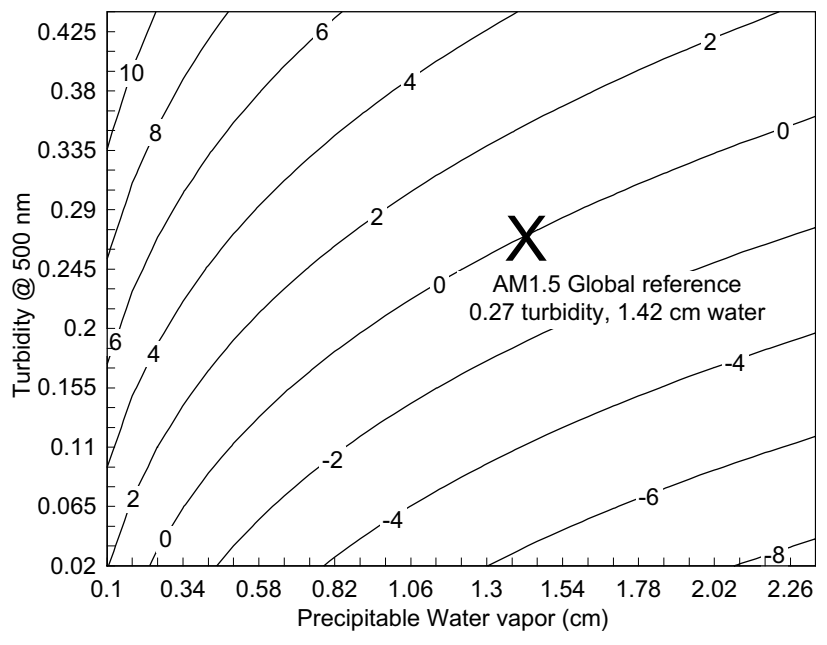

Fig. 9. Percentage deviation from the global reference spectrum at AM 1.5 for the top cell of a triple junction a-Si module light soaked for 1000 hours at $50{ }^{\circ} \mathrm{C}$ and one-sun.

The air-mass spectral correction procedure assumes that the only factor influencing the spectral correction factor is air mass. This assumption has been shown to be acceptable for certain sites and for PV technologies that have a low sensitivity to spectral variations with water vapor and turbidity such as mono-Si.

\section{SUMMARY}

Spectral corrections of data measured under natural sunlight based on the air mass are only an approximation. The error introduced by the assumption that the spectrum at AM1.5 is the reference spectrum may be small enough to be of use in correcting field data where measuring the spectrum is not practical. Using a matched reference cell to measure the total irradiance further reduces the uncertainty in the spectral correction but makes the correction equation dependant on the detector used. The air mass based spectral correction factor is location and time dependant.

\section{ACKNOWLEDGEMENTS}

This work was supported in part under DOE contract DE-AC36-99G010337.

\section{REFERENCES}

[1] K.A. Emery, C.R. Osterwald, T.W. Cannon, D.R. Myers, J. Burdick, T. Glatfelter, W. Czubatyj, and J. Yang, "Methods for Measuring Solar Cell Efficiency Independent of Reference Cell or Light Source," Proc. 18th IEEE PV Spec. Conf., Las Vegas, NV, October 21-25, 1985, pp. 623-628, IEEE, New York, 1985.
[2] H. Field and K. Emery, "An Uncertainty Analysis of the Spectral Correction Factor," Proc. 23rd IEEE Photovoltaic Specialists Conf., Louisville, KY, May 10-14, 1993, pp. 11801187, IEEE, New York.

[3] D.L. King, J.A. Kratochvil, W. E. Boyson, and W. Bower, "Field Experience with a New Performance Characterization procedure for Photovoltaic Arrays," Proc. 2nd World Conference and Exhibition on Photovoltaic Solar Energy Conversion, Vienna, Austria, July 6-10, 1998, Joint Research Center report EUR 18656, pp. 1947-1952.

[4] C.R. Osterwald, "Calculated Solar Cell I $\mathrm{sc}_{\mathrm{sc}}$ Sensitivity to Atmospheric Conditions under Direct and Global Irradiance," Proc. 18 ${ }^{\text {th }}$ IEEE PV Spec. Conf., Las Vegas, NV, October 21-25, 1985, pp. 951-956, IEEE, New York, 1985.

[5] Standard IEC 60904-1, Photovoltaic devices Part 1: Measurement of Photovoltaic Current-Voltage Characteristics, International Electrotechnical Commission, Geneva, Switzerland.

[6] Standard ASTM E891-92, "Standard for Terrestrial Solar Direct Normal Solar Spectral Irradiance Tables for Air Mass 1.5," Amer. Society for Testing Matls., West Conshocken, PA, USA.

[7] C. Helmke, W. Zaaiman, G. Agostinelli, J. M. Ruiz, J. Alonso, A. Marti, F. Schomann, and W. Schmidt, "Reproducibility Characterization of Aspire Pilot Line Samples," Proc. 2nd World Conference and Exhibition on Photovoltaic Solar Energy Conversion, Vienna, Austria July 6-10, 1998, Joint Research Center report EUR 18656, pp. 1415-1417. 


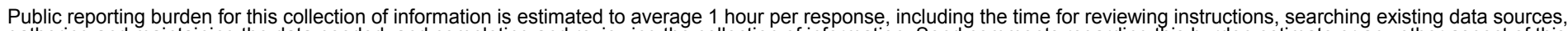

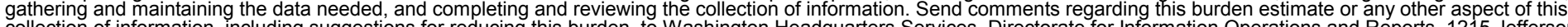
Davis Highway, Suite 1204, Arlington, VA 22202-4302, and to the Office of Management and Budget, Paperwork Reduction Project (0704-0188), Washington, DC 20503.

\begin{tabular}{|l|l|l|}
\hline 1. AGENCY USE ONLY (Leave blank) & $\begin{array}{l}\text { 2. REPORT DATE } \\
\text { May } 2002\end{array}$ & $\begin{array}{l}\text { 3. REPORT TYPE AND DATES COVERED } \\
29^{\text {th }} \\
\text { IEEE PVSC-Conference Paper } \\
\text { May 20-24 2002 }\end{array}$ \\
\hline
\end{tabular}

4. TITLE AND SUBTITLE

Spectral Corrections Based on Optical Air Mass: Preprint

6. AUTHOR(S)

K. Emery, J. DelCueto, and W. Zaaiman*
5. FUNDING NUMBERS PVP23401

8. PERFORMING ORGANIZATION REPORT NUMBER

National Renewable Energy Laboratory, 1617 Cole Blvd., Golden, CO 80401-3393

*European Commission Joint Research Centre, Institute for Environment and Sustainability, Renewable Energies, Italy

9. SPONSORING/MONITORING AGENCY NAME(S) AND ADDRESS(ES)

National Renewable Energy Laboratory

1617 Cole Blvd.

Golden, CO 80401-3393

AGENCY REPORT NUMBER

NREL/CP-520-31399

11. SUPPLEMENTARY NOTES

12a. DISTRIBUTION/AVAILABILITY STATEMENT

National Technical Information Service

12b. DISTRIBUTION CODE

U.S. Department of Commerce

5285 Port Royal Road

Springfield, VA 22161

13. ABSTRACT (Maximum 200 words): This conference paper describes the measurement of the photovoltaic (PV) performance with respect to reference conditions requires measuring the performance with respect to a reference spectrum. Procedures were developed in the mid 1980s to correct measurements for errors relating to the spectral irradiance of the light source being different from the standard and the responsivity of the irradiance detector being different from the device under test. In principle, these procedures are exact, but require the measurement of the spectral irradiance of the light source and responsivity of the test device. This is problematic for most facilities that measure module performance. It has been suggested that a polynomial fit of the shortcircuit current $(\mathrm{I}$ sc $)$ measured under natural sunlight divided by the total broadband irradiance as a function of air mass provides an accurate spectral correction factor. The polynomial correction factor is normalized to unity at an absolute air mass of 1.5. The polynomial correction factor is compared with the spectral correction factor for a variety of devices at two locations. short-circuit current; direct-normal light;

15. NUMBER OF PAGES

16. PRICE CODE

17. SECURITY CLASSIFICATION OF REPORT Unclassified
18. SECURITY CLASSIFICATION OF THIS PAGE Unclassified
19. SECURITY CLASSIFICATION OF ABSTRACT Unclassified
20. LIMITATION OF ABSTRACT

UL

NSN 7540-01-280-5500

Standard Form 298 (Rev. 2-89) Prescribed by ANSI Std. Z39-18 